\title{
СУЧАСНІ МЕТОДИ ВИЯВЛЕННЯ ЗБУДНИКА ТУБЕРКУЛЬОЗУ ТА ЙОГО МЕДИКАМЕНТОЗНОЇ ЧУТЛИВОСТІ ПРИ ТУБЕРКУЛЬОЗІ ОРГАНІВ ДИХАННЯ
}

\author{
Тернопільський державний медичний університет ім. І.Я. Горбачевського, \\ Тернопільський обласний протитуберкульозний диспансер
}

Проаналізовано результати молекулярно-генетичного дослідження системою Gene Xpert MBT/RIF 1449 зразків харкотиння, взятих у осіб, що зверталися в тубдиспансер. 3 одного зразка харкотиння одночасно виконували також мікроскопію мазка і посіви на живильне середовище. Такий же аналіз проведено у 53 стаціонарних хворих-бактеріовиділювачів. Встановлено високу чутливість молекулярно-генетичного тесту щодо виявлення мікобактерій туберкульозу та їх стійкості до рифрампіцину, яка була близькою до результатів культурального методу. Найменш ефективною щодо виявлення мікобактерій була мікроскопія мазків харкотиння.

Ключові слова: туберкульоз, методи виявлення збудника, медикаментозна чутливість.

В останні десятиріччя 20-го століття сподівання на швидке викорінення туберкульозу призвели до занепаду протитуберкульозної служби, призупинення наукових досліджень, спрямованих на удосконалення діагностики і лікування цієї недуги. Проте, поширення ВІЛ-інфекції і хіміорезистентності збудника туберкульозу зумовили сплеск смертності та висунули нові задачі перед дослідниками.

Розшифрування в 1998 р. генома мікобактерії туберкульозу, а відтак генетичної суті їх медикаментозної стійкості, дало можливість створити нові діагностичні системи, які дозволяють не лише швидко діагностувати захворювання на туберкульоз, але одночасно визначати резистентність збудника до протитуберкульозних препаратів і своєчасно призначати адекватну хіміотерапію [1]. До таких діагностичних систем належить тестсистема Gene Xpert MBT/RIF (компанії Cepheid), якою користуються протитуберкульозні заклади III рівня [2]. Це тест напівкількісної полімеразної ланцюгової реакції в реальному часі, що застосовується з метою виявлення ДНК Mycobacterium tuberculosis у зразках харкотиння, а також мутацій генів гроВ, пов'язаних із стійкістю до рифрампіцину. Результати тестування отримують через 1 год 45 хв.

Стійкість до рифрампіцину зазвичай супроводжується стійкістю до інших препаратів, найчастіше до ізоніазиду, що є ознакою мультирезистентного туберкульозу (МРТБ), результати лікування якого залежать від своєчасного призначення адекватної хіміотерапії [3]. Тест характеризується високою чутливістю стосовно виявлення МБТ у хворих (від 73,1 до 97,8 \%) і специфрічністю в осіб без туберкульозу (99 \%). За встановленням стійкості до рифрампіцину чутливість становить $97,2 \%$ в осіб, що виділяють стійкі МБТ; специфрічність при чутливості до рифрампіцину сягає 98,3\% [4].

Метою дослідження був порівняльний аналіз клінічної цінності тесту Xpert MBT/RIF та інших методів для підтвердження діагнозу туберкульозу та встановлення медикаментозної чутливості збудника.

\section{Матеріали і методи}

Досліджено 1449 зразків харкотиння з використанням молекулярно-генетичного (МГ) тесту Xpert MBT/RIF від пацієнтів, які звертались амбулаторно або поступали для стаціонарного обстеження. Одночасно з цього ж зразка виконувалася мікроскопія мазка (М) та посіви на тверде середовище (Левенштейна-Йенсена) і рідке живильне середовище (система ВАСТЕС) для отримання культури (К) мікобактерій і визначення ії медикаментозної чутливості. Порівнювалися результати цих трьох методів. Паралельні аналізи різними методами 3 одного зразка харкотиння дозволяли уникнути помилок, пов'язаних з кількістю мікобактерій в різних зразках, якістю збору і транспортування матеріалу, попередньої антибіотикотерапії і т.д.

Більш детальний аналіз клінічного значення цих методів дослідження проведений у 53 хворих на туберкульоз легень, що лікувалися стаціонарно і в яких констатовано бактеріовиділення будь-яким з перелічених методів. 


\section{Результати досліджень та їх обговорення}

Із 1449 зразків харкотиння, тестованих на апараті Xpert MBT/RIF, позитивний результат про присутність ДНК мікобактерій (МГ+) отримано у 331 випадку. Ці результати показали велике співпадіння з найбільш надійним культуральним методом. Так, у 317 пацієнтів із 331, або 95,8 \%, вони були підтверджені культурально $(\mathrm{K}+)$. МГ-аналіз був одночасно значно інфрормативнішим від мікроскопії мазка харкотиння, яка виявилася негативною (М-) у 155 (46,8 \%) із 331 зразка з МГ+. Проте у 14 зразках харкотиння, або 4,2 \% випадків, результати аналізу на Xpert MBT/RIF щодо присутності ДНК мікобактерій (MГ+) не були підтверджені ні мікроскопією мазка, ані культуральним методом. Це можна було б пояснити недостатньою кількістю мікобактерій в зразках, неправильним зберіганням харкотиння чи в окремих випадках - присутністю нежиттєздатних мікобактерій, які не дали росту на живильному середовищі. Тому клінічне значення тесту в кожному конкретному випадку слід оцінювати лише співставляючи весь комплекс результатів клініко-лабораторного і рентгенологічного обстеження хворих [5].

Не менш важливою метою проведення МГ-тесту є встановлення можливої стійкості МБТ до рифампіцину. Серед 331 дослідженого зразка з МГ+ стійкість до рифрампіцину (Рифр+) виявлено у 113 (34,1\%), і у 109 випадках (96,5 \%) це було підтверджено культурально. Культуральне дослідження також встановило у 1083 113 зразків (95,6 \%) одночасно стійкість до ізоніазиду (мультирезистентність).

Таким чином, МГ-тест є цінним і достатньо надійним, хоча і дорогим, методом швидкої діагностики туберкульозу і резистентності збудника до рифрампіцину, що дозволяє оперативно коригувати хіміотерапію. За своєю інформативністю він близький до культуральних методів, результати яких лікар отримує із значним запізненням.

Враховуючи, що придбання тест-системи та їі використання в наших закладах стало можливим за фрінансової підтримки міжнародних фрондів, її слід використовувати з суворим дотриманням всіх рекомендацій щодо відбору пацієнтів для дослідження, щоби уникнути можливих помилкових результатів.

Більш детальний аналіз клінічного значення різних методів пошуку мікобактерій туберкульозу і визначення їх хіміорезистентності проведено у групі з 53 хворих на туберкульоз легень, які проходили стаціонарне лікування. У всіх них констатовано бактеріовиділення, встановлене будь-яким з перелічених методів: мікроскопією мазка харкотиння, посівом на тверде або рідке живильне середовище або молекулярно-генетичним методом. Вказані дослідження також проводилися 3 одного зразка харкотиння.
Серед хворих було 36 чоловіків і 13 жінок віком від 21 до 72 років. Поступали на лікування вперше (ВДТБЛ) 44 пацієнти, повторно (рецидиви - РТБЛ) - 9. Деструкції легеневої тканини виявлені у 13 осіб. У 3 хворих встановлено ко-інфекцію ВІЛ/ТБ, в одного - цукровий діабет II типу, в 1 - поєднання туберкульозу з метастатичним канцероматозом.

У найбільшої кількості обстежених підтвердження бактеріовиділення отримано культуральним методом $(\mathrm{K}+)$ - 48 хворих (90,5 \%), дещо менше за допомогою МГ+ - у 38 пацієнтів (71,7 \%) і найменше - при мікроскопії мазка $(\mathrm{M}+)$ - 13 осіб (24,5\%). Отже, найбільш інформативним, хоча недостатньо швидким був культуральний метод. Це ще раз підтверджує велике значення МГ-тесту, при якому отримують швидкий результат. 3 його допомогою отримано позитивні результати у 27 (50,9 \%) хворих з негативною мікроскопією (М-) і у 4 (7,5 \%) з М- і К-, в яких динамічним спостереженням і результатами лікування підтверджений діагноз туберкульозу.

Другою важливою метою було виявлення резистентності збудника до рифампіцину. Позитивні результати за МГ-аналізом щодо стійкості до рифрампіцину (Риф+) отримано у 4 хворих. У 3 із них це було підтверджено культурально (2 - мультирезистентність, 1 - розширена резистентність до 7 протитуберкульозних препаратів). У 1 пацієнта стійкість до рифампіцину не могла бути підтверджена культурально через відсутність росту колонї̆ МБТ як на рідкому, так і на твердому середовищі. Цей випадок розглядали як РифТБ і хворому призначено повноцінну терапію препаратами II ряду з добрим клініко-рентгенологічним ефектом. Слід відмітити, що стійкість до рифампіцину (Риф+) була виявлена у 3 пацієнтів з вперше діагностованим туберкульозом, а методом культивування ще у 4. У загальному різні види хіміорезистентності при ВДТБЛ встановлено у 22 із 44 (50\%) таких хворих, що свідчить про високий рівень первинної стійкості до протитуберкульозних препаратів, якими вони ніколи не лікувались.

Із 3 пацієнтів 3 ко-інфекцією ТБ/ВІЛ у двох виявлено мікобактерії методом МГ і лише в одного мікроскопією мазка (M+), але у всіх були позитивні результати культивування (K+), за якими у всіх трьох встановлено резистентність до протитуберкульозних препаратів (монорезистентність - 1, полірезистентність - 2).

Окремої уваги заслуговують результати мікроскопії мазка харкотиння, якому в сучасній стратегії боротьби 3 туберкульозом приділяється велика роль як методу виявлення туберкульозу, так і контролю за есрективністю лікування [6]. Як вказано вище, серед 53 хворихбактеріовиділювачів результати М+ отримано лише у 13 хворих (24,5\%). В той же час у 20 із 40 осіб з М- 
(50 \%), в яких бактеріовиділення встановлено іншими методами, констатовано резистентність збудника до тих чи інших препаратів (у т. ч. полірезистентність - 11, мультирезистентність - 1), що співзвучне з матеріалами [5]. Треба вважати, що рекомендації щодо можливості переведення на амбулаторне лікування пацієнтів, у яких отримано 2 негативні результати мікроскопії мазка [6], епідеміологічно необґрунтовані. Більш оправданим і безпечним для сім'ї і оточення хворого $є$ його перебування в стаціонарі до отримання негативних результатів культурального дослідження.

\section{Висновки}

1. Tест Xpert MBT/RIF є швидким і надійним методом виявлення в зразках харкотиння МБТ та їх стійкості до рифрампіцину. Результати тесту співпадали у 95,8 \% 3 результатами культурального дослідження щодо виявлення МБТ і у 95,6 \% щодо їх стійкості до рифрампіцину.

2. Серед хворих-бактеріовиділювачів, що поступали в стаціонар, кислотостійкі бактерії методом мікроскопії мазка харкотиння виявлено лише у 24,5 \% осіб, а у 50 \% пацієнтів з негативними результатами мікроскопії культуральним методом констатовано різні варіанти стійкості збудника до протитуберкульозних препаратів. Тому переведення хворих на амбулаторне лікування епідеміологічно оправдано лише після отримання негативних результатів культивування.

\section{Література}

1. Phillips L. Infection disease: TB's revenge / L. Phillips // Nature. - 2013. - Vol. 493. - P. 14-16.

2. Gene Xpert. Xpert MBT/RIF Assay (компанія Cepheid). - May 2012. - $266 \mathrm{p}$.

3. Ковальова Г.Г. Актуальні питання та практичні підходи до підвищення ефективності загальнодержавної програми протидії захворюванню на туберкульоз в Україні / Г.Г. Ковальова // Туберкульоз, легеневі хвороби, ВІЛ-інсекція. - 2013. - № 4. - С. 14-22.
4. Rapid molecular detection of tuberculosis and rifampicin resistance / [C.C. Boehme, P. Nabeta, D. Hillemann et al.] // N. Engl. J. Med. - 2010. - Vol. 363. - P. 1005-1015.

5. Контингенти хворих з групи високого ризику щодо мультирезистентного туберкульозу $\mathrm{RIF}(+)$ за результатами обстеження хворих за допомогою Gene Xpert MBT/RIF / C.О. Черенько, A.O. Варицька, А.І. Барбова, П.С. Трофимова // Туберкульоз, легеневі хвороби, ВІЛ-інфекція. -2014. - № 4 (19). - С. 29-33.

6. Наказ МОЗ України від 04.09.2014 р. № 620 Унісрікований клінічний протокол первинної, вторинної (спеціалізованої) та третинної (високоспеціалізованої) медичної допомоги дорослим. Туберкульоз. - 197 с

\section{MODERN METHODS OF TUBERCULOSIS PATHOGEN DETECTION AND IT DRUG SENSITIVITY IN LUNG TUBERCULOSIS PATIENTS}

M.M. Savula, N.M. Lopushanska, L.P. Prots, N.V. Medetska

SUMMARY. Sputum examination was performed on one sample using molecular genetic testing on Gene Xpert MBT/RIF, sputum microscopy and culture plating for tuberculosis pathogen. Evaluation were performed on 1449 sputum samples that were obtained in tuberculosis dispensary. The same tests were performed on 53 patients from the hospital with MBT positive sputum. It was shown high molecular genetic test sensitivity for MBT detection and evaluation of it resistance to rifampicin. Similar results were obtained from culture detection. Sputum microscopy examination was less informative for MBT detection.

Key words: tuberculosis, methods of exciter exposure, medicinal sensitiveness.

Отримано 26.01.2016 p. 